\title{
Hypercalcaemia és veseelégtelenség - merre induljunk?
}

\author{
Garam Nóra dr. ${ }^{1}$ - Tislér András dr. ${ }^{1}$ - Pethő Ákos dr. ${ }^{1}$ \\ Ledó Nóra dr. ${ }^{1}$ - Kárpáti Ágnes dr. ${ }^{1}$ - Fehér Ágnes dr. ${ }^{1}$ \\ Kardos Magdolna dr. ${ }^{2}$ - Csomor Judit dr. ${ }^{3}$ - Takács István dr. ${ }^{1}$ \\ ${ }^{1}$ Semmelweis Egyetem, Általános Orvostudományi Kar, Belgyógyászati és Onkológiai Klinika, Budapest \\ ${ }^{2}$ Semmelweis Egyetem, Általános Orvostudományi Kar, II. Patológiai Intézet, Budapest \\ ${ }^{3}$ Semmelweis Egyetem, Általános Orvostudományi Kar, I. Patológiai és Kísérleti Rákkutató Intézet, Budapest
}

Közleményünkben egy 63 éves férfi esetét ismertetjük, aki fáradékonyság, fogyás miatt végzett laboratóriumi vizsgálatokon igazolódó veseelégtelenség és hypercalcaemia miatt került felvételre Klinikánkra. A területen végzett röntgenvizsgálaton a koponyán frontalisan és a sacrumon csonteltérések (temporofrontalisan 13 mm-es, körülírtabb, mérsékelten intenzív árnyék és az Sl-es rés sclerosisa) ábrázolódtak, ultrahangvizsgálat során lépmegnagyobbodás volt látható. Tünetei hátterében endokrin vagy malignus betegség nem igazolódott. A háttérben elsősorban myeloma multiplex merült fel, ugyanakkor azt célzott vizsgálatokkal sem megerősíteni, sem kizárni nem lehetett, így csontvelőbiopszia történt. A vesefunkció-romlás okának tisztázása végett vesebiopsziát végeztünk, melynek előzetes eredménye interstitialis nephritist véleményezett óriássejtekkel. Az angiotenzinkonvertáló enzim szérumszintjének ez okból történő vizsgálata emelkedett szintet mutatott, így esetünket Boeck-sarcoidosis extrapulmonalis manifesztációjának tartottuk. Per os szteroidkezelésre a beteg tünetei egyértelmú regressziót mutattak. A csontvelő- és vesebiopszia eredménye megerősítette a Boeck-sarcoidosis diagnózisát. A sarcoidosis ezen extrapulmonalis formája hypercalcaemiával és veseérintettséggel - de tüdőérintettség nélkül - rendkívül ritka, különös tekintettel a vesét érintő formára. Hypercalcaemia nagyjából 7,9\%-ban, veseelégtelenség 1,4\%-ban fordul elő. Ezen eset alapján fontos hangsúlyozni, hogy a hypercalcaemia és a veseelégtelenség hátterében a gyakoribb endokrin, malignus, hematológiai okok mellett a Boecksarcoidosisnak is fel kell merülnie a differenciáldiagnosztika során.

Orv Hetil. 2021; 162(13): 514-518.

Kulcsszavak: sarcoidosis, hypercalcaemia, veseelégtelenség

\section{Hypercalcemia and renal insufficiency - where can we start?}

We present the case of a 63-year-old male patient who was admitted to our Clinic with fatigue, weight loss, hypercalcemia, renal insufficiency and anemia. X-ray showed lesions on the frontal skull and sacral region. On abdominal ultrasound, splenomegaly was detected. Based on these, myeloma multiplex was the most likely initial diagnosis; this, however, could not be confirmed with targeted serum tests, therefore bone marrow biopsy was performed. To clarify the underlying cause of decreased kidney function, renal biopsy was performed, the preliminary results of which revealed interstitial nephritis accompanied by giant cells. Serum angiotensin converting enzyme level was elevated, which led to the diagnosis of Boeck sarcoidosis with extrapulmonary manifestations. Oral corticosteroid therapy was commenced that was followed by regression of the patient's symptoms and laboratory abnormalities. Both the bone marrow and the kidney biopsies supported the diagnosis of Boeck sarcoidosis. Presentation of sarcoidosis with hypercalcemia and renal insufficiency but without the involvement of the lungs is extremely rare. Hypercalcemia occurs in about $7.9 \%$ and renal insufficiency in $1.4 \%$ of the cases. Based on this case, it is important to highlight that in the background of hypercalcemia and renal failure - beside the more frequent causes such as endocrine and hematological diseases, malignancy - one is to consider the possibility of Boeck sarcoidosis as well.

Keywords: sarcoidosis, hypercalcemia, renal insufficiency

Garam N, Tislér A, Pethő Á, Ledó N, Kárpáti Á, Fehér Á, Kardos M, Csomor J, Takács I. [Hypercalcemia and renal insufficiency - where can we start?]. Orv Hetil. 2021; 162(13): 514-518.

(Beérkezett: 2020. július 31.; elfogadva: 2020. augusztus 31.) 


\section{Rövidítések}

anti-CCP = ciklikus citrullinált peptid elleni antitest; CA = (cancer antigen) rákantigén; $\mathrm{CD}=$ (cluster of differentiation) differenciációs klaszter; CEA = carcioembrionalis antigén; CT = $($ computed tomography $)$ számítógépes tomográfia; DNS = dezoxiribonukleinsav; ds-DNS = dupla szálú DNS; Hgb = hemoglobin; Ig = immunglobulin; HIV = humán immundeficientiavirus; PSA = prosztataspecifikus antigén; s-ACE = (serum angiotensin-converting enzyme) szérum-angiotenzinkonvertálóenzim; SS-A = Sjögren-szindróma-A-antitest; SS-B = Sjögren-szindróma-B-antitest

\section{Esetismertetés}

2019. szeptemberben egy 63 éves férfi beteg jelentkezett a Semmelweis Egyetem Belgyógyászati és Onkológiai Klinikájának nefrológiai ambulanciáján progrediáló veseelégtelenség, hypercalcaemia miatt. Korábbi anamnézisében érdemi megbetegedés nem szerepelt. Többször volt traumás sportsérülése, illetve 2018. júniusban orrszárnyáról basaliomát távolítottak el.

2019 nyarán kezdődő fáradékonyság, hasi fájdalom, fogyás miatt kereste fel háziorvosát. Ekkor laboratóriumi leletei anaemiát, emelkedett kreatininértékeket mutattak (120 $\mu \mathrm{mol} / \mathrm{l})$. A területen végzett hasi ultrahang splenomegaliát véleményezett. A röntgenvizsgálat a koponyán temporofrontalisan és a sacrumon csontlaesio lehetőségét vetette fel, temporofrontalisan $13 \mathrm{~mm}$-es, körülírtabb, mérsékelten intenzív árnyék és az $\mathrm{Sl}$-es rés sclerosisa ábrázolódott. Ezt követően a háziorvos a vesefunkció-beszúkülés tisztázása végett nefrológiai ambulanciánkra irányította a beteget. Az itt végzett kontrollvizsgálaton az anaemia és a vesefunkció romlását tapasztaltuk, hypercalcaemia (3,02 mmol/l) mellett. További kivizsgálásra Klinikánk nefrológiai osztályára felvettük.

A fizikális vizsgálat során az ultrahangon is leírt megnagyobbodott lépen kívül egyéb kórosat nem találtunk. A vizeletvizsgálat emelkedett összfehérje/kreatinin hányadost (143 mg/mmol) mutatott, mely emelkedés elsősorban nem a fokozott albuminürítésnek volt köszönhető (albumin/kreatinin hányados: 11,8 mg/mmol). A hypercalcaemia fokozott kalciumürítéssel társult a vizeletben (vizelet kalcium/kreatinin: 1,9 mmol/mmol). A beteg felvételkori laborjában az ismert anaemián ( $\mathrm{Hgb}$ : $114 \mathrm{~g} / \mathrm{l}$ ) és beszúkült vesefunkción (kreatinin: 227 umol/l) kívül gyorsult süllyedés $(48 \mathrm{~mm} / \mathrm{h})$ igazolódott. Nemcsak az összes $(2,75 \mathrm{mmol} / \mathrm{l})$, hanem az ionizált kalcium (1,43 mmol/l) szintje is emelkedett volt.

Az egy év alatt fokozatosan kialakuló hypercalcaemia és csökkent vesefunkció okának kivizsgálását endokrin, hematológiai, onkológiai és immunológiai betegség irányában kezdtük meg (1. táblázat). A hypercalcaemia

1. táblázat |A hypercalcaemia differenciáldiagnosztikája, illetve társulása veseérintettséggel

\begin{tabular}{|c|c|c|c|c|}
\hline \multirow{2}{*}{\multicolumn{3}{|c|}{ Etiológia }} & \multicolumn{2}{|c|}{ Veseérintettség } \\
\hline & & & Speciális & Általános \\
\hline \multirow[t]{3}{*}{ PTH-mediált } & \multicolumn{2}{|c|}{ Primer hyperparathyreosis } & - & $\begin{array}{l}\text { Nephrolithiasis } \\
\text { Nephrocalcinosis }\end{array}$ \\
\hline & \multicolumn{2}{|c|}{ Familiaris hypocalcuriás hypercalcaemia } & - & Nephrolithiasis nem jellemző \\
\hline & \multicolumn{2}{|c|}{$\begin{array}{l}\text { Malignomához társult } \\
\text { - ectopiás PTH-szekréció } \\
\text { - PTHrP-termelésen alapuló }\end{array}$} & - & \multirow[t]{6}{*}{$\begin{array}{l}\text { Nephrolithiasis } \\
\text { Nephrocalcinosis vesefunkció- } \\
\text { romlás }\end{array}$} \\
\hline \multirow[t]{5}{*}{$\begin{array}{l}\text { Nem } \\
\text { PTH-mediált }\end{array}$} & \multicolumn{2}{|c|}{$\begin{array}{l}\text { Malignomához társult } \\
\text { - osteolyticus folyamathoz társult } \\
\text { - 1,25-dihidroxi-vitamin-D-mediált }\end{array}$} & - & \\
\hline & \multicolumn{2}{|c|}{ - Myeloma multiplex } & $\begin{array}{l}\text { - Könnyúlánc-nephropathia } \\
\text { (myelomavese) } \\
\text { - Könnyűlánc-amyloidosis }\end{array}$ & \\
\hline & \multirow[t]{2}{*}{$\begin{array}{l}\text { D-vitamin-függő } \\
\text { aktiváció }\end{array}$} & $\begin{array}{l}\text { Sarcoidosis } \\
\text { Tuberculosis } \\
\text { Berylliosis } \\
\text { Coccidioidomycosis } \\
\text { Histoplasmosis }\end{array}$ & $\begin{array}{l}\text { Granulomatosus interstitialis } \\
\text { nephritis }\end{array}$ & \\
\hline & & D-vitamin-intoxikáció & - & \\
\hline & Egyéb ritka okok & $\begin{array}{l}\text { Hyperthyreosis } \\
\text { Acromegalia } \\
\text { Phaeochromocytoma } \\
\text { Hypadrenia } \\
\text { Immobilizáció } \\
\text { Ammóniummérgezés } \\
\text { Gyógyszerek (lítium, tiazid) }\end{array}$ & - & \\
\hline
\end{tabular}

$\mathrm{PTH}=$ parathormon; PTHrP = parathormonrokon fehérje 
eredetének tisztázására először a beteg parathormonszintjét néztük meg, mely csökkent volt $(6 \mathrm{pg} / \mathrm{ml})$, így a mellékpajzsmirigy-eredetet kizártuk.

A beteg magas kalciumszintje, illetve a fogyás miatt felmerült a malignus eredet is, esetleges csontérintettséggel. Tumormarkerszintjei (PSA, CEA, CA19-9, CA72-4) mind a normáltartományban voltak. Hasi ultrahangvizsgálat során az ismert hepatosplenomegalián kívül egyéb kóros nem igazolódott, nephrocalcinosis sem ábrázolódott. Mivel szekunder csontfolyamat is felvetődött, az alkalikus foszfatáz csontban jellemző izotípusát is megvizsgáltuk, ez is a normáltartományban volt.

A röntgenen leírt csontérintettség, a hypercalcaemia, a romló vesefunkció, illetve a vizeletben lévő, nem albumin típusú fehérje alapján bennünk elsősorban a myeloma multiplex lehetősége merült fel, így vizsgálatainkat ebben az irányban folytattuk. Mind a vizeletben, mind a szérumban emelkedett kappa- és lambda-könnyúláncszinteket mértünk, ám arányuk nem volt kóros (vizelet $\kappa / \lambda=1,58$; szérum $\kappa / \lambda=0,89$ ), ami nem jellemző a betegségre. Emelkedett IgA- és IgM-szinteket mértünk, szérumelektroforézissel mind az $\alpha 1$-, mind a $\gamma$-globulinfrakció emelkedett volt. Immunfixáció során monoklonális komponens jelenléte egyértelmüen nem volt kizárható. Mivel a területen készült röntgenfelvételen mind a koponyán, mind a sacrumon csonteltéréseket írtak le, ezeket a felvételeket megismételtük, melyek ezeken a területeken már nem mutattak elváltozásokat. A csontfolyamat egyértelmû tisztázása végett ezekről a régiókról CT-felvétel is készült, mely csontérintettséget szintén nem igazolt. A degeneratív elváltozásokon kívül osteolyticus területek nem ábrázolódtak. A perifériás vérből készült kenetben microcyter vörösvértestek voltak láthatók, plazmasejtek nem voltak jelen. Mivel ezen vizsgálatokkal sem egyértelmúen megerősíteni, sem kizárni nem tudtuk a myeloma multiplex jelenlétét, a betegség egyértelmû tisztázására a betegnél csontvelő-biopszia elvégzését láttuk indokoltnak. Amíg ennek vizsgálati lelete készült, addig a differenciáldiagnosztikai útvonalon továbbhaladtunk.

Elsősorban nefrológiai szempontból közelítve meg a kérdést, a vesefolyamat hátterében immunológiai folyamat lehetősége merült fel. A vizsgált immunológiai markerek közül enyhén pozitív antinukleárisantitest- és reumafaktorszinteket kaptunk. Az összes többi vizsgált autoimmun antitest negatív eredményt adott (SS-A, SS-B, ds-DNS elleni antitest, anti-CCP stb.). A nefrológiai folyamat tisztázása céljából vesebiopszia történt, mely kifejezetten nehéz mintavételnek bizonyult. A biopsziás tü nehezen tudott áthatolni a vesetokon, ami a tapasztalatok alapján szintén myeloma multiplexre volt gyanús, ám a biopszia előzetes lelete az immunbetegség fennállását kizárta, viszont interstitialis nephritist véleményezett óriássejtekkel. Myelomás vesére utaló elváltozásokat az előzetes vizsgálaton nem láttak.

Habár a mellkasröntgenen semminemú kóros nem ábrázolódott, a hypercalcaemia és a vesebiopszia előzetes lelete alapján a Boeck-sarcoidosis lehetősége is felmerült, így szérum-angiotenzinkonvertálóenzim (s-ACE)-szintet mértünk, mely a betegben emelkedett volt (112,1 $\mathrm{U} / 1$; normáltartomány: 20-70 U/1). A s-ACE-szint gyakran emelkedett granulomatosus betegségekben, de emellett különböző vírusfertőzésekben (coccidioidomycosis, tuberculosis, toxoplasmosis, HIV) is $[1,2]$. A Boeck-sarcoidosisban szenvedő betegekben a magasabb s-ACE-szint elsősorban az epitheloid granulumokban jelen lévő, fokozott ACE-expressziónak köszönhető, ugyanakkor a vizsgálat specificitása és szenzitivitása is alacsony. Bár az emelkedett s-ACE-szint a sarcoidosis esetében diagnózisalkotásra nem alkalmas, a klinikai gyanút erősíti, ahogy esetünkben is történt $[3,4]$.

Így a kezünkben levő eredmények alapján a betegséget a sarcoidosis extrapulmonalis manifesztációjának véleményeztük, ezért per os kortikoszteroidterápiát (napi 64 mg kezdő dózisban) indítottunk. A terápia mellett mind a kalcium $(2,52 \mathrm{mmol} / \mathrm{l})$, mind a kreatinin (145 mmol/l) szintje csökkenni kezdett. Az 1 hónapos kontrollvizsgálat alkalmával a $\mathrm{Hgb}$ emelkedett (133 g/l), a kreatinin $(121 \mathrm{mmol} / \mathrm{l})$ és a kalcium $(2,52 \mathrm{mmol} / \mathrm{l})$ további csökkenést mutatott. Ekkorra mind a csontvelö-, mind a vesebiopszia lelete elkészült.

A vesebiopszia alapján a patológus diffúzan kiszélesedett interstitiumot véleményezett gyulladásos beszürődéssel, fóként lymphocytákkal, elszórtan plazmasejtekkel és eosinophil granulocytákkal. Emellett az interstitiumban granulomatosus gyulladás volt látható, centrumában epitheloid histiocyták mellett többmagvú óriássejtekkel. Nekrózis a granulumok területén nem volt látható. Ziehl-Neelsen-féle festéssel saválló pálcák jelenléte nem volt igazolható. A látott kép alapján felmerült a Boecksarcoidosis lehetősége (1. ábra).

A csontvelő-biopsziás mintában a csontvelőben néhány, epitheloid sejtekből és többmagvú óriássejtből álló, nem elsajtosodó kis granuloma volt megfigyelhető, melyeket laza, CD3-pozitív T-sejtekból álló udvar vett körül. Néhány kis CD3-pozitív lymphoid góc a granulomáktól függetlenül is megfigyelhető volt. Számottevő plazmasejt-szaporulat a hematoxilin-eozin metszetekben nem volt látható (2. ábra). Az áramlási citometria során kóros fenotípusú plazmasejtek nem voltak láthatók. A látott kép alapján a patológusok enyhén hipercelluláris kiérő vérképzést, mérsékelt fokú erythroid hyperplasiát, granulomatosus gyulladást véleményeztek, mely szintén megfeleltethető a Boeck-sarcoidosisnak.

Összevetve a klinikai képet és a kapott eredményeket, a látott képet a Boeck-sarcoidosis extrapulmonalis manifesztációjának tartottuk, bár a tüdőérintettséget egyértelmúen nem tudjuk kizárni, mivel mellkas-CT-vizsgálat nem - csak mellkasröntgen - történt, mely negatív eredményt adott. Sajnos a diagnózisalkotásban az arany standard jelenleg hiányzik. A sarcoidosis klasszifikációjában döntő jelentősége a mellkasröntgennek van. Irodalmi adatok szerint a CT-vizsgálat ehhez csak nagyon kevés esetben tud hozzátenni. A legtöbb betegnél felesleges a 


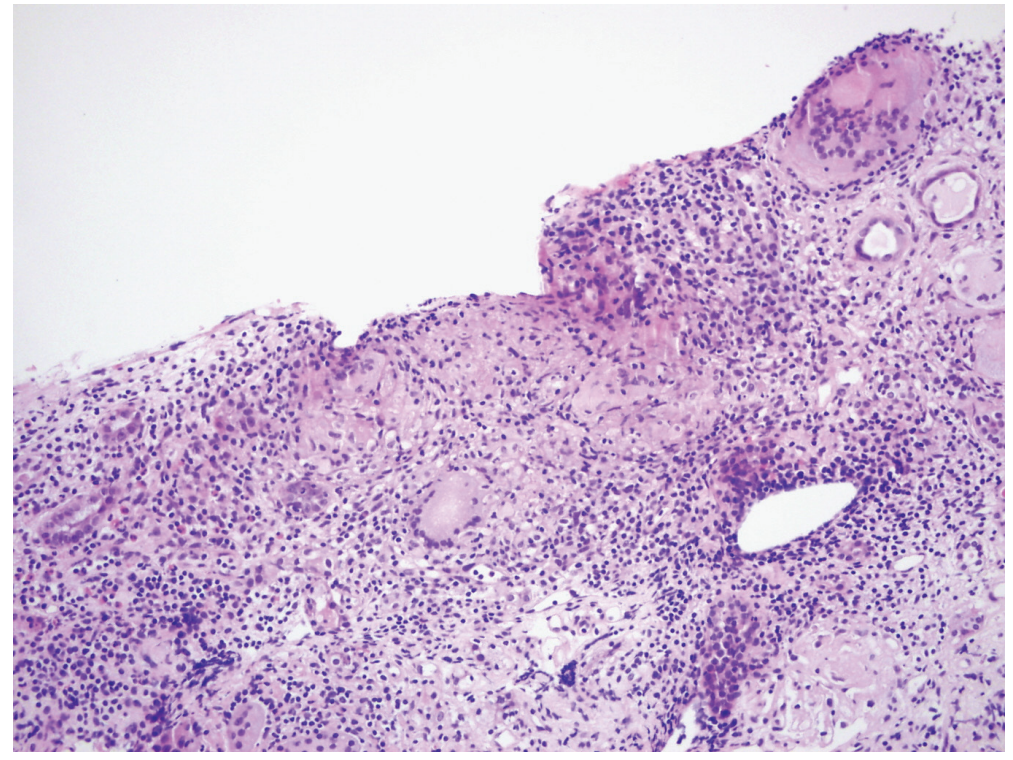

1. ábra | Óriássejtes granulumok a vesebiopsziás képen (hematoxilin-eozin festés, nagy nagyítás)

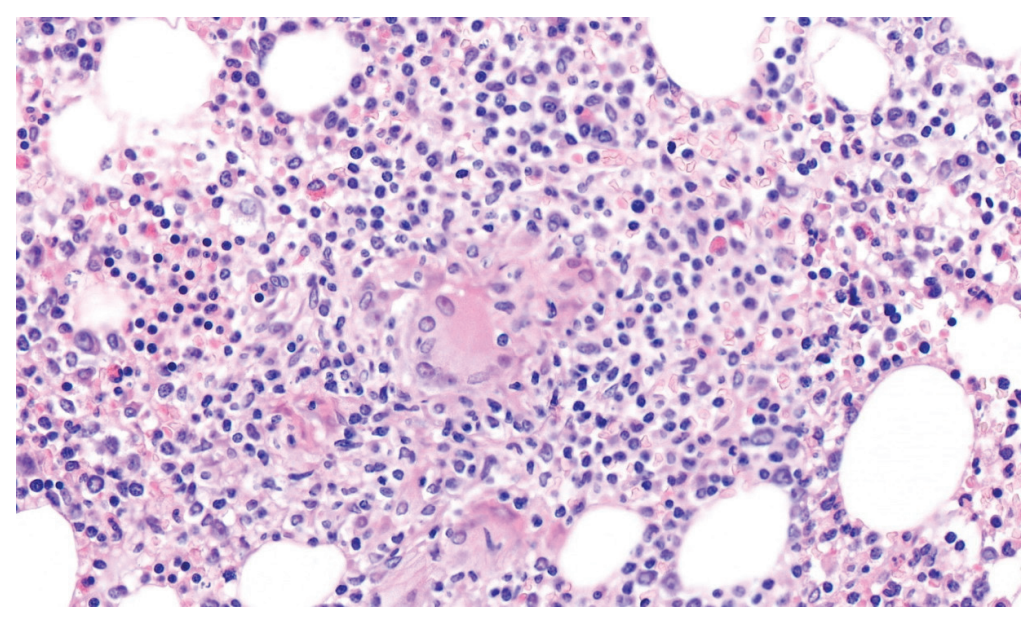

2. ábra

A beteg csontveló-biopsziából nyert anyagának hematoxilin-eozin festett nagy nagyítású képe, melyen néhány, epitheloid sejtekből és többmagvú óriássejtből álló, nem elsajtosodó kis granuloma látható

mellkas-CT elvégzése, kivéve azokban az esetekben, amikor a röntgen atípusos elváltozásokat ír le, vagy vérköpés jelentkezik a negatív radiológiai kép ellenére [47]. Mivel a beteg az empirikusan megkezdett, per os szteroidterápiára rapid javulást mutatott, további diagnosztikus lépések elvégzését terápiás konzekvencia hiányában nem tartottuk indokoltnak, így pótlólag CT-vizsgálat sem történt. A diagnózist a klinikum, a laboreredmények és a szövettani mintavételek együttese megerősítette.

\section{Megbeszélés}

A Boeck-sarcoidosis egy idiopathiás granulomatosus megbetegedés, melynek hátterében a T-lymphocyták és makrofágok fokozott aktivációja áll $[8,9]$. A hisztológiai képet el nem sajtosodó granulumok jellemzik óriássejtekkel, melyek bármelyik szervet érinthetik. Elsődlegesen, a leggyakrabban a tüdőben manifesztálódik, hilaris lymphadenopathia jellemzi, tüdőérintettséggel. Az ese- tek 10\%-ában erythema nodosummal társul, mely a diagnózisalkotásban segítséget nyújthat $[5,10]$.

A Boeck-sarcoidosissal diagnosztizált esetek nagyjából 50\%-ában jelentkezik a kórkép valamilyen extrapulmonalis manifesztációja. Ez a leggyakrabban a bőrt érinti, még akkor is, ha az erythema nodosumot nem számítjuk bele ezekbe a börre lokalizálódó folyamatokba $[10,11]$. Azok a betegek, akiknek a tüdejükön kívül egyéb szervükben is jelen van a betegség, általában hosszabb kezelési időszakkal, fokozott relapsushajlammal rendelkeznek [11].

Ennél jóval ritkábbak azok az esetek, amikor a tüdőérintettség teljesen hiányzik a betegeknél, és csak valamelyik más szervrendszerben manifesztálódik a sarcoidosis - ez az esetek 5-9\%-ában fordul elő [10, 11]. Ezekben az esetekben is a bőrt érintő manifesztáció a leggyakoribb ( 25\%). A mi betegünknél jelen levő két tünet - a sarcoidosis renalis $(1,4 \%)$ érintettsége, illetve a hypercalcaemia $(7,9 \%)$ - a ritkábbak közé sorolandó [11]. 
Sarcoidosisban hypercalcaemiát először 1981-ben írtak le [12]. A hypercalcaemia hátterében a sarcoidosisos betegekben az aktív D-vitamin (kalcitriol) endogén túlprodukciója áll, melyet az aktivált makrofágok fokozott 1-alfa-hidroxiláz-aktivitása okoz [13].

Esetünkben a veseérintettséget primer folyamatnak tartottuk, nem a hypercalcaemia következményének, melyet a vesebiopszián leírt óriássejtes, interstitialis gyulladás is megerősített, illetve az, hogy a hasi ultrahangon nephrocalcinosisra utaló jelet nem láttunk. Ez a leggyakrabban leírt hisztológiai kép azokban a sarcoidosisos esetekben, amikor a veseérintettség jelen van a betegeknél. Sajnos a pontos prevalenciája nem ismert. Azokban az esetekben, amelyekben a veseérintettség felmerült, biopsziás mintákban nagyjából $20-50 \%$ közé tehető az előfordulása [14].

Ezen esetünk közlését egyrészról azért tartjuk fontosnak, mert a sarcoidosis ritka megjelenési formájával találkoztunk, mely elsősorban a vesét érintette, illetve hypercalcaemiával jelent meg. Másrészről fontos kiemelni, hogy a hypercalcaemia, illetve a veseelégtelenség együttes megjelenése mennyi különböző kórképben fordulhat elő, a belgyógyászat megannyi területét érintheti, lehet endokrin, immunológiai, nefrológiai, hematológiai és onkológiai vonatkozása egyaránt. Mint láthatjuk, sokszor a laboreredmények és a képalkotó metodikák eredményei alapján sem lehet egyértelmúen felállítani a diagnózist.

Harmadrészről esetünk azért is tanulságos, mivel sokszor az egy irányba mutató eredmények, illetve tünetek alapján felmerült betegség, prekoncepciók - esetünkben primeren elsősorban a hematoonkológiai myeloma multiplex - esetében sem szabad eltekinteni a korrekt differenciáldiagnosztikai lépésektől. Mindig fel kell, hogy merüljenek a kérdőjelek, körül kell járni az adott problémát. Itt szeretnénk hangsúlyozni különösen a patológiai mintavétel fontosságát, hiszen esetünkben az adta meg elsősorban a diagnózist. Ez vezetett rá bennünket a s-ACE vizsgálatára, melynek bár sem a specificitása, sem a szenzitivitása nem elég magas ahhoz, hogy egyértelmú diagnózist állítsunk fel [4], az eredmény jelentős adalék volt, és ennek birtokában, illetve a vesebiopszia előzetes lelete alapján már ki tudtuk mondani a Boeck-sarcoidosis diagnózisát, és adekvát kezelésben tudtuk részesíteni betegünket.

A terápia megkezdését követően betegünk kétszer jelentkezett nefrológiai ambulanciánkon kontrollvizsgálaton, legutóbb 2020 februárjában. Ez idő alatt kalciumszintje a normáltartományban volt, szignifikáns vesefunkció-romlást nem tapasztaltunk. Ezt követően sajnos a beteg a vizsgálatokon nem jelent meg.
Anyagi támogatás: A szerzők a közlemény elkészítésével kapcsolatban nem részesültek anyagi támogatásban.

Szerzői munkamegosztás: G. N.: Irodalomkutatás, a kézirat megszövegezése. G. N., T. A.: A beteg ellátásában való részvétel. P. Á., L. N.: A vesebiopszia elvégzése. K. Á., F. Á.: A csontvelő-biopszia elvégzése, hematológiai szakértők. Cs. J., K. M.: A minták patológiai értékelése. T. A., L. N., T. I.: A kézirat szakmai véleményezése. A cikk végleges változatát valamennyi szerző elolvasta és jóváhagyta.

Érdekeltségek: A szerzőknek nincsenek érdekeltségeik.

\section{Irodalom}

[1] Lopez-Sublet M, Caratti di Lanzacco L, Danser AH, et al. Focus on increased serum angiotensin-converting enzyme level: from granulomatous diseases to genetic mutations. Clin Biochem. 2018; 59: 1-8.

[2] Brice EA, Friedlander W, Bateman ED, et al. Serum angiotensinconverting enzyme activity, concentration, and specific activity in granulomatous interstitial lung disease, tuberculosis, and COPD. Chest 1995; 107: 706-710.

[3] Silverstein E, Pertschuk LP, Friedland J. Immunofluorescent localization of angiotensin converting enzyme in epithelioid and giant cells of sarcoidosis granulomas. Proc Natl Acad Sci Unit States Am. 1979; 76: 6646-6648.

[4] Ungprasert P, Carmona EM, Crowson CS, et al. Diagnostic utility of angiotensin-converting enzyme in sarcoidosis: a population-based study. Lung 2016; 194: 91-95.

[5] Iannuzzi MC, Rybicki BA, Teirstein AS. Sarcoidosis. N Engl J Med. 2007; 357: 2153-2165.

[6] Soto-Gomez N, Peters JI, Nambiar AM. Diagnosis and management of sarcoidosis. Am Fam Physician 2016; 93: 840-848.

[7] Bargagli E, Prasse A. Sarcoidosis: a review for the internist. Intern Emerg Med. 2018; 13: 325-331.

[8] Hunninghake GW, Crystal RG. Pulmonary sarcoidosis: a disorder mediated by excess helper T-lymphocyte activity at sites of disease activity. N Engl J Med. 1981; 305: 429-434.

[9] Thomas PD, Hunninghake GW. Current concepts of the pathogenesis of sarcoidosis. Am Rev Respir Dis. 1987; 135: 747-760.

[10] Baughman RP, Teirstein AS, Judson MA, et al. Clinical characteristics of patients in a case control study of sarcoidosis. Am J Respir Crit Care Med. 2001; 164: 1885-1889.

[11] James WE, Koutroumpakis E, Saha B, et al. Clinical features of extrapulmonary sarcoidosis without lung involvement. Chest 2018; 154: 349-356.

[12] Barbour GL, Coburn JW, Slatopolsky E, et al. Hypercalcemia in an anephric patient with sarcoidosis: evidence for extrarenal generation of 1,25-dihydroxyvitamin D. N Engl J Med. 1981; 305: $440-443$

[13] Gwadera Ł, Białas AJ, Iwański MA, et al. Sarcoidosis and calcium homeostasis disturbances - do we know where we stand? Chron Respir Dis. 2019; 16: 1479973119878713.

[14] Hilderson I, Van Laecke S, Wauters A, et al. Treatment of renal sarcoidosis: is there a guideline? Overview of the different treatment options. Nephrol Dial Transplant. 2014; 29: 1841-1847.

(Garam Nóra dr.,

Budapest, Korányi Sándor u. 2/a, 1083 e-mail: norigaram@gmail.com)

A cikk a Creative Commons Attribution 4.0 International License (https://creativecommons.org/licenses/by/4.0/) feltételei szerint publikált Open Access közlemény, melynek szellemében a cikk bármilyen médiumban szabadon felhasználható, megosztható és újraközölhető, feltéve, hogy az eredeti szerző és a közlés helye, illetve a CC License linkje és az esetlegesen végrehajtott módosítások feltüntetésre kerülnek. (SID_1) 